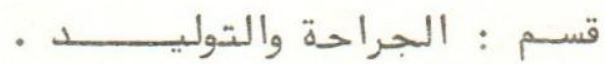

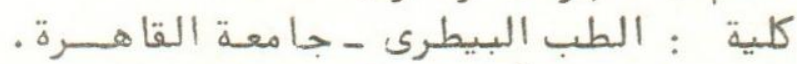

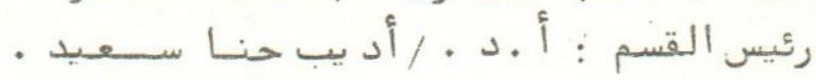

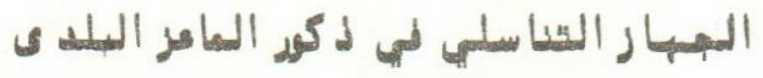
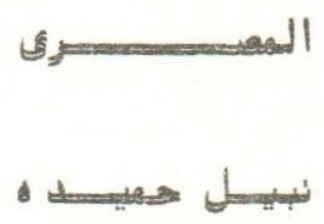

اجريت هـذه الد راسة على الجههاز التناسلي لعدد د حب من ذكور الماعسز

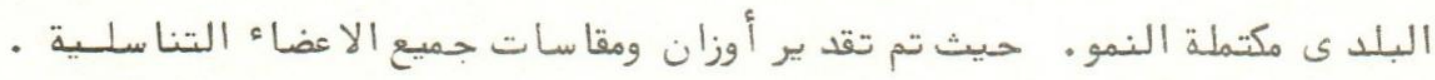

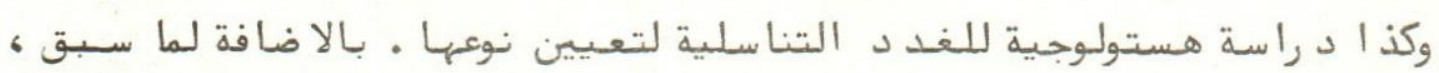

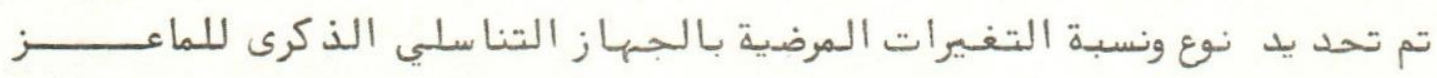
البلــدى . اتضح من الد راسة ما يليى :

أوزان ( متوسط بـ الانحراف المعيارى ) الخصيه ؛ البربخ ، غدة الحويصلة

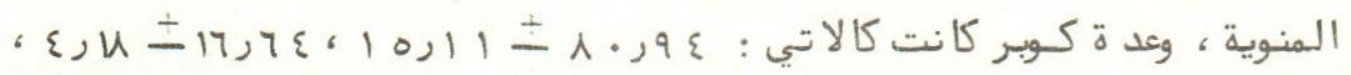

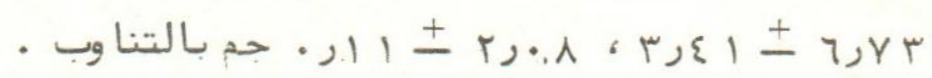

r) تناسق وزن ومقاسات وشكل الاعضاء التناسلية سكلا الناحيتين اليمنــــــ

$$
\text { واليسرى . }
$$

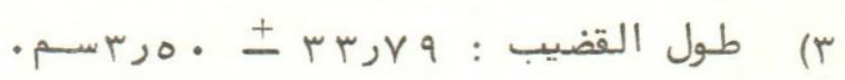

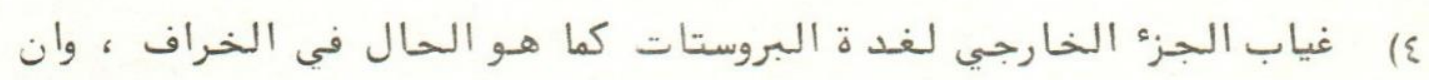

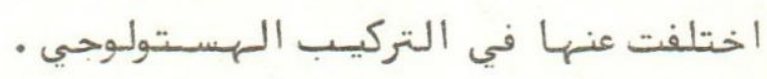

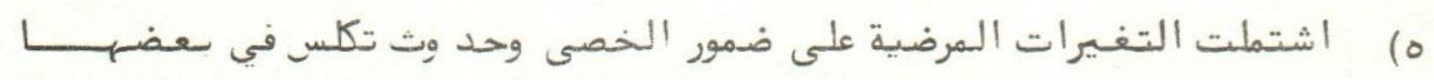

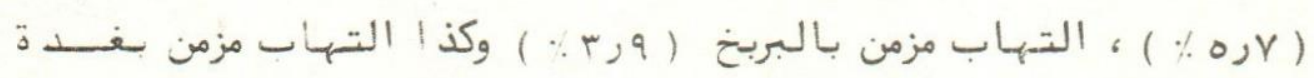

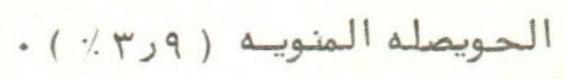



Dept. of Surgery \& Theriogenology,

Faculty of Vet. Med.. Cairo University,

Head of Dept. Prof. Dr. A.H. Said.

\title{
THE REPRODUCTIVE TRACT OF THE CAPRINE EGYPTIAN BALADY BUCKS
}

(With 8 Figures)

\author{
By \\ N.A. HEMEIDA \\ (Received at 16/10/1984)
}

\begin{abstract}
SUMMRY
Reproductive tracts of twenty-six mature Balady bucks were utilized in this investigation. Weihts of the testis, epididymis, vesicular gland and bulbo-urethral gland averaged $80.94 \pm 15.11,16.64+4.18$, $6.73 \pm 3.41$ and $2.08 \pm 0.11 \mathrm{gm}$ respectively. Penis was $\overline{33} .79 \pm$ $3.50 \mathrm{~cm}$ iong. Measurements of other reproductive organs were given. Right and left side organs were symmetrical in size and shade. Accessory glanas were also examined histologically to study their microscopic structure.

Abnormalities of the reproductive organs in the Balady goat included testicular atrophy and calcification $5.7 \%$, chronic epididymitis $3.9 \%$ and chronic interstitial vesiculitis $3.9 \%$.
\end{abstract}

\section{INTRODUCTION}

Despite the areat amount of informaion now available on the reproductive tracts of domestic farm animals. little attention has been paid to the male reproductive tract of the goat. Anatomist have assumed for man vears that the male caprine reproductive tract was almost simiiar to the ovine species SISSON. 1921; NICKEL. SCHUMMER, SEIFERLE and SACK, 1973: GETTY, 1975.

Morpholog: of the male genital organs is essential for predicting their functional activity. Sperm production rates could be determined from the testicular measurements (FOOTE, HAHN \& LAP.SON. 1970: LINO. 1972: COULTER and FOOTE, 1976). However, information regarding moronologv anc biometerics $\sigma^{;}$the testis. and other genital organs of the goat is verv sparse Y 40 and EATON. 1954: LGBOELI. OPARCACHA and LEIGH, 1978: KUNDU, 1980). As yet, no data are availabie on similar asdects in the Egvotian Balady goats.

The obiectives of the present study were a) to determine biometrics of the normal genita organs of the mature Egyptian Balad bucks. b to stud the microscopic anatomy of the accessor glands in order to consolidate the information regarding the similarity of the microscodic structure of the genitalia of ram and the caprine male. and $c$ to determine incidence and type of abnormalities in the genital organs of the Balady bucks.

\section{MATERIALS and METHODS}

A total number $\sigma^{\prime}$ twentı-six health Balady bucks were utilized in this study. The age and body weight of the animal ranged setween 2 to 4 vears and 31 to $45 \mathrm{~kg}$.

Gross examintior of the sebroductive organs and their dimensions and weights were recorded immediatels after sacrifing the animals. Small pieces of both testes. epididymides,

Assiut Vet. Med. J. Vol. 14, No. 28, 1985. 


\section{N.A. HEMEIDA}

and amoulla ductus deferens. paired vesicular glands. pelvic urethra. Daired bulbo-urethral alands and Denis were fixed in Bouin's solution within 1 to 2 hours after slaughter. Tissues were dehvdrated via gradec alcohois. cleared is benzene ano embedded in paraffin wax. Sections were cut at $6 \mathrm{um}$ and stained with haematoxylin and eosin for histopathological examination.

Statistical analysis of the data was done according to SNEDECOR and COCHRAN (1976).

\section{RESULTS}

\section{Testes:}

The testicles of the Balady goat were elongated and ovoid (Fig. 1). The longitudinal axis was vertica: and the atached border bein posterior. Left and right testes measured (mean - SE $6.77=0.42$ and $0.75 \pm 0.39$ in iength. $4.32 \pm 0.48$ and $4.38 \pm 0.52$ in width and 4.76 $\pm 0.4^{-}$anc $4.8 \mathrm{C}=0.46 \mathrm{~cm}$ in the anterior-posterior diameter. Testis weight for both left and right sides averagec $80.7^{-}=18.2^{-}$and $81.15 \pm 19.80 \mathrm{gm}$ respectively. Differences in testis dimensions and weight between left and right sides were not statistically significant.

Testicular abnormaitites were reported in 3 out of the 52 testes examined (5.7\%). They included testicular atrophy. sperm stasis and calcification. The two atrophied testicles were smaller and firmer than normal on gross examination, fibrosed and lacked turgidity when incised (Fig. 2). Testis tunic was thickened and accompanied by adhesions with the surrounding. On histopathology. many of the seminiferous tubules disappeared leaving abundant interstitial fibrous tissue witr accumulations of plasma cells. The few seminiferous tubules left showed advanced stages of degeneratior.

The calcified testis showed whitish deposits in the parenchyma when incised (Fi. 3). in nistological examination. the testis showed an extensive fibrosis of the interstitium and sperm stasis and calcification of the seminiferous tubules (Fig. 4).

\section{Epididymis and Ductus Deferense:}

Left and right epididymides weignec $16.56 \pm 4.90$ and $16.70 \pm 4.62 \mathrm{gm}$ respectively, with no sianificant difference between both sides. Caput. corpus and caudal portions comprised $45.4 \%$. $17.5 \%$ ano $37.0 \%$ respectively of the total epididymal weight.

Ductus deferense tota! length and diameter averaged $37.57 \pm 8.92$ and $0.32 \pm 0.10 \mathrm{~cm}$. Ampulie auctus aeferense was $8.26=3.04 \mathrm{~cm}$ long and $0.70 \pm 0.20 \mathrm{~cm}$ in diameter.

Chronic edidiaumitis was noted in 2 goats comnrising an incidence of $3.9 \%$. The inflammed edididvmides were harc anc aporoximateis five times the weight of the normal epididymis. or nistooatnolool. edididuma! umen was filled with neutrophils. lymphocytes ad proteinacious naterials. Markec cellulat infiltration. sDerm granulomas and fibrosis were also seen in the inerstitia tissue.

\section{Vesicular glands:}

The vesicuia: gianas of the Balad goats were relatively very large paired compact gianduiat organs with a lobulatec surface Fi. 5 . The measured $3.6 \pm 0.4$ in thickness. the riant and lef: glanas were symmetrical in snape and size.

-istorogicall. the vesicular gaanc was divided into large and small lobules by thick fibromuscular sedta. The gianc was found to de of the compouno tubular type. Secretory tubules 


\section{THE REPRODUCTIVE TRACT OF THE CAPRINE EGGYPTIAN BALADY BUCKS}

were lined by simple columnar epithelium. Columnar cells of variable hight, were occupied by spherical nuclei in their basal half.

Chronic vesiculitis was recorded in one buck comprising an incidence of $3.9 \%$ Inflammed vesicular glands were not noticeable grossly, but histological examination revealed marked cellular infiltration of the interstitial tissue and fibrosis. Lymphocytes, plasma cells and histocytes predominated. Neutrophil leucocytes were also scattered in moderate numbers in the interstitial tissue.

\section{Prostate gland:}

The prostate gland in the goat was represented only by pars disseminata, the corpus prostate was lacking. The disseminated prostate gland formed a layer completely surround the pelvic urethra. which was $7.1 \pm 0.8 \mathrm{~cm}$ in length and $1.5+0.1 \mathrm{~cm}$ in width. The thickness of the glandular tissue increased toward the mid-dorsal region of the pelvic urehra.

Histologically, the prostate gland was found to be branched tubular in type. The interlobular tissue, made of a large amount of smooth muscle, demarcated the prostatic tissue into incomplete loules. Secretory units showed a progressive decrease in size toward the posterior part of the peivic urethra. The units were also widely separated by increasing amount of connective tisue posteriorly. The secretory linning of the prostate tubules was made of simple columnar or cuboidal epithelium.

\section{Bulbo-urethral glands:}

The bulbourethral glands of the Balady bucks were large, dense, spherical organs, 1.50 $\pm 0.06 \mathrm{~cm}$ in diameter and $2.08 \pm 0.11 \mathrm{gm}$ in weight. They were situated on either side at the ischial end of the pelvic urethra (Fig. 5). Histologically, the bulbo-urethral gland was compound tubulo-alveolar in type (Fig. 8). The secretory tubules and alveoli were lined wih cuboidal to columnar cells and possessed wide to narrow lumina. The secretory-cell cytoplasm was lightly stained and vacuolated. The nuclei were oval and basally situated.

\section{Penis:}

The peins in the Balady goats measured $33.79 \pm 3.50 \mathrm{~cm}$ in total lengh and $1.27 \pm$ $0.15 \mathrm{~cm}$ in diameter at the level of the preputial reflections. The anterior tip of the penis was free of the prepuce for $4.0 \pm 0.1 \mathrm{~cm}$ and the galea glandis was $1.97 \pm 0.10 \mathrm{~cm}$ long. The urethral process was $1.84 \pm 0.26 \mathrm{~cm}$ long. Just behind the scrotum, about $1 / 3$ of the penis $10.11 \pm 0.85 \mathrm{~cm}$ was folded up forming the sigmoid flexure.

\section{DISCUSSION}

Weights and measurements of the testes and other reproductive organs reported herein for Baiady goats were. in general, comparable to the values recorded for Billy, Saanen and Nubian goats (HEINEMANN, 1937; RICHTER, 1959; FIELDEN and BARKER, 1964; NICKEL et ai.. 1973), but higher than those of Toggenberg, Sudanese and Jamnapari goats (YAO and EATON. 1954: EL-AZAB and IMBAI, 1979; KUNDU, 1980). However, much larger testis weight was reported in Biliv bucks (SCHLUMPERGES, 1954). Differences in breed, age, body weight, season, inheritane and nutritional regimes could be responsible factors for such variations YAO and EATON, 1954: DAVIES. MAN and RAWSON, 1957; VAN DEMARK and MAUGER, 1964; FOOTE, 1969; ABDOU. HASSUN and ELSAWAF. 1978; KUNDU. 1980).

Assiut Vet. Med. J. Vol. 14, No. 28, 1985. 


\section{N.A. HEMEIDA}

The finding that the left and right side organs were symmetrical in shape and size, was in accord with he observations of HEUMER (1942) in the same species, WEISGOLD and ALMQUIST (1979) in bulls. ABDOU et al. (1978) in rams and GEBAUER, PICKETT \& SWIERSTRA (1974 in stallions. However KUNDU (1980) noted that in Jamnapari goats, the right vesicular gland was heavier and larger than the left one.

Histologicai examination of the accessory glands showed that the microscopic structure of the vesicular giands was similar in both Balady and Jamnapari goats (KUNDU,1980). However, YAO and EATON 1954) in Toggenburg bucks and Aitken (1959) in rams observed two types of cells, chief columner and few basal cells lining the secretory tubules. The finding that the disseminated prostate gland formed a layer completely surround the pelvic urethra was in accord with observations in the same species NICKEL et al.. 1973; GETTY, 1975; KUNDU, 1980), whereas in rams it formed ventrally an in complete ring in the urethral muscle (AITKEN, 1959; NICKEL et al., 1973; GETTY, 1975). Despite this difference, the microscopic structure of the prostate giand in both species was similar (YAO and EATON, 1954; AITKEN, 1959; KUNDU, 1980. The observed variation in height of cells lining the secretory units of the bulbo-urethrai glands could be attributed to their secretory activity (WROBEL, 1970).

Reports on Dathology of the male reproductive organs in the goat are very few. The finding that testicular abnormalities averaged $5.7 \%$ and that the commonest lesions were testicular atrophy. fibrosis and calcification was in good agreement with the incidence ( 2.3 to $10.4 \%$ and type of abnormalities reported in other breeds of goat (MATHEW and RAJA, 1979: VINHA. SANTOS and HUMENHUK, 1980). Among the goats studied herein, abnormalities in other reproductive organs were found to be chronic epididymitis ( $3.9 \%$ ) and vesiculitis $3.9 \%$. The histodanological changes observed herein were similar to those which have been described in other animais (LANCASTER, 1956; WATT. 1972: MCENTEE, 1977).

\section{REFERENCES}

Abdou. M.S.. Hassun. T.M. and El-Sawaf, S. (1978): Testicular and epididymal sperm numbers and related Darameters in the developing Awassi ram. Aust. J. Biol. 31, 257 266.

Aitken. R.N.C. 1959): Observations on the development of the seminal vesicles, prostate and bulbourethral glands in the ram. J. Anat. 93, $43-51$.

Coulter. G.H. anc =oote. R.H. 1976): Effect of season and year of measurement of testicular growth and consistency of Holstein bulls. J. Anim. Sci. 42. 434.

Davies. D.V.. Mann. -. and Rowson, L.E. (1957): Effect of nutrition on the onset of male sex hormone and sDerm formation in menozygous bull-calves. Proc. Roy Soc. $3147.332-351$.

E-Azac. E.A. anc imbabi. S.E. (1979): Reproductive performance of male Sudanese goats. . Testicular and edididymal sDerm reserves. Zagazig Vet. J. 2, 31 - 38.

Fieider. E.D. and Barker. C.A.C. 1964: Semen collection studies and sperm reserves in the goat. 5 th int. Congr. Anim. Redrad. A.l. (Torento 4. 488.

Foot. R.H. 1969): Research technique to study reproductive physiology in the male. In "Techniaues and Procedures in Animal science Research" pp. 80 - 110. Amer. Soc. Anim. Sci.

foote. R.h.. Hann. J. and Larson. L.L. 1970): Testicular measurements as predictors of sperm output and semen aualitı. 3rd. Tech. Confr. on A.l. and Reprod. p. 31.

Gebauer, M.P... Pickett. B.W. and Swierstrá. E.E. (1974): Reproductive physiology of the stallion. II Daiiv Droduction and output of sperm. J. Anim. Sc. 39, 732.

Assiut Vet. Med. J. Vol. 14, No. 28, 1985. 


\section{THE REPRODUCTIVE TRACT OF THE CAPRINE EGYPTIAN BALADY BUCKS}

Getty, R. (1975): Sisson and Grossman's the Anatomy of the Domestic Animals. 5th Ed., Philadeinhia. W.B. Saunders Co.

Heinemann, K. 1937): Eining, Muskeln de mannlichen Geschlechtsapparates der Haussangetiere. Diss. Med. Vet. Hannover.

Heumer, H. 1942): Testicular size of fertile and sterile billy goats. Inaug. Diss. Hannover Abst. in Dtscn. Tierarztle Wschr. 51, 54).

igboeti. G.. Obarcacha. G.O. and Leigh. J.V. (1978): The reproductive tract of the small short earec male. Zambia j. Sci. \& Technology 1, 131 - 135.

Kundu. P.S. 1980): Anatomical studies on the accessory male glands (Gross and microscopic) of the indian goat Jamunapari and cross amunapari). Indian J. Anim. Health 19 , $15:-153$.

Lancaster. M.C. 1956): A study of Dathological changes in the testicles of A.l. bulls. Proc. 3rd int. Congr. Anim. Reprod. A.i.. Cambridge.

Lino, B.F. 1972): The output of spermatozoa in rams. 11 relationships to scrotal circumference, testis weight. and the number of sDermatozoa in different parts of the urogenital tract. Aust. J. Bioi. Sci. 25. 359 - 366.

Mathew, J. anc Raia. C.K. 1979: incidence of testicular degeneration in goats. Kerala J. Vet. Sci. 10, $206-211$.

McEntee. K. (1977): Lecture notes for the course "Reproductive Pathology of Domestic Animals" Cornell University, Ithaca. New York.

Nickel, R.. Schummer. A.. Seiferle. E. and Sack, W.O. (1973): The viscera of the domestic mammais. Veriag Paul Parey. Berlin. Hamburg.

Richter, W. (1959): Observations of the penile development of the Angora goat. Amer. J. Vet. Res. 20. 603 - 606.

Schlumberger, O.V. 1954): Der Nebenhoden und seine Lage zum Hoden bei Rind, Schaf und Ziege. Diege. Jiss. Med. Vet. nannover.

Sisson. 5. 1921): The anatomy of the domestic animais. 2nd Ed. Philadelphia, W.B. Saunders Combanv.

Snedecor. .W. and Cochran. W.G. 1976: Statistical methods. 6th Ed., lowa state College Press, Ames. U.S.A.

VanDemark. N.L. anc Mauger, R.E. (1964): Effect of energy intake on reproductive performance of dair sulls. 1 . Growth of reproductive organs and puberty. J. Dairy Sci $47.788-802$.

Vinhe. N.A.. Santos. M.R. and Humennuk. R.A. (1980): Preliminary observations on the pathology of testis anc edididymis in goats. V. Testicular lesions. Arquivos da Escola de Veterina -ria de Univ. Federal de minas Gerais 32, 7 - 13.

Watt. D.A. (1972): Testicular abnormaities and spermatogenesis of the ovine and other species. vet. Buti. 42. 181 - 190 .

Weisgoic. A.O. and Almauist. 3.O. (1979): Reproductive capacity of beef bulls. Vi. Daily spermatozoal production. SDermatozoai reserves and dimensions and weight of reproductive oroans. J. Animi. 5ci. 48. 351 - 358.

wrode. K.-.. 1970: Untersuchangen Zur Feinstrukture und Histochemie der Glandula Bulbourethraiis de: Ziege. Z. Zelforsch. $108-582$.

Yao. T.S. and Eaton, O.N. 1954): Postnatal growth and histological development of reproductive organs in maie goats. Amer. J. Anat. $95.401-432$.

Assiut Vet. Med. J. Vol. 14, No. 28, 1985. 


\section{N.A. HEMEIDA}

\section{DESCRIPTION OF FIGURES}

Fig. (1): Testis of a mature Balad buck.

Fig. (2): Testicular atroph and chronic epididymitis.

Fig. (3): Incised calicfied testis showing whitish deposits.

Fig. (4): Section of the calcified testis showing makerd fibrosis, advanced degeneration of seminferous tubules and calcium deposits in some tubules ( $H$ \& $E$ stain; $180 X)$.

Fig. (5): Accessory giands of an adult Balady goat.

Fig. (6): Section of the vesicular gland showing alveoli lined with columnar epithelium ( $H$ \& E stain: $180 \mathrm{X}$ ).

Fig. (7): Section of the prostate gland in the posterior part of the pelvic urethra showing increased amount of connective tissue surrounding the glandular part ( $H$ \& $E$ stain; $180 \mathrm{X}$.

Fig. (8): Section of the bulbourethral gland showing alveoli lined with high columnar or cuboidal epithelium ( $H$ \& $E$ stain: $180 \mathrm{X}$ ).

Assiut Vet. Med. J. Vol. 14, No. 28, 1985. 


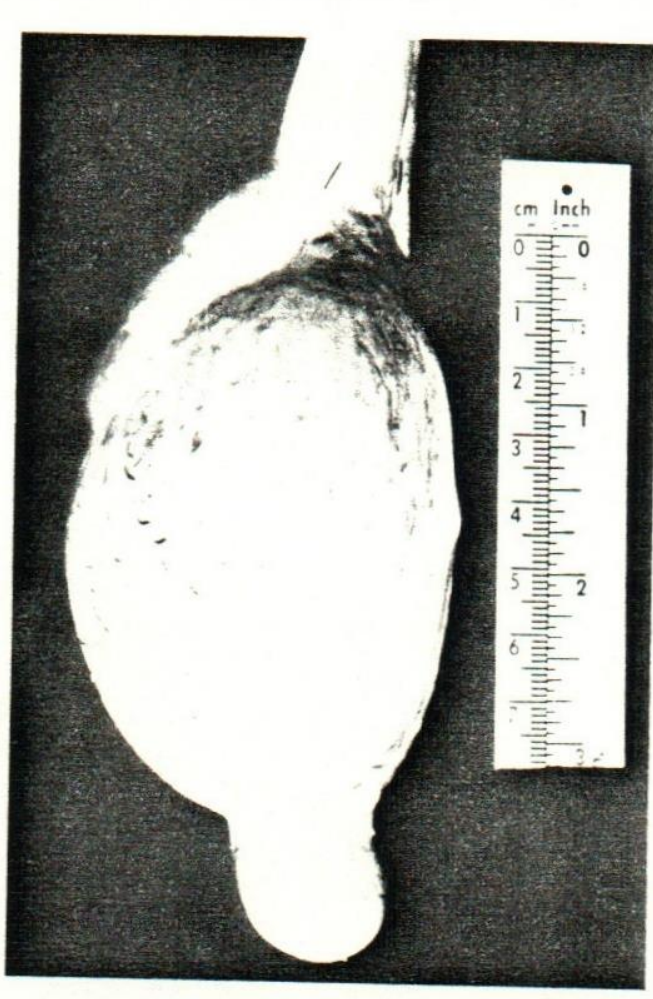

Fig. (1)

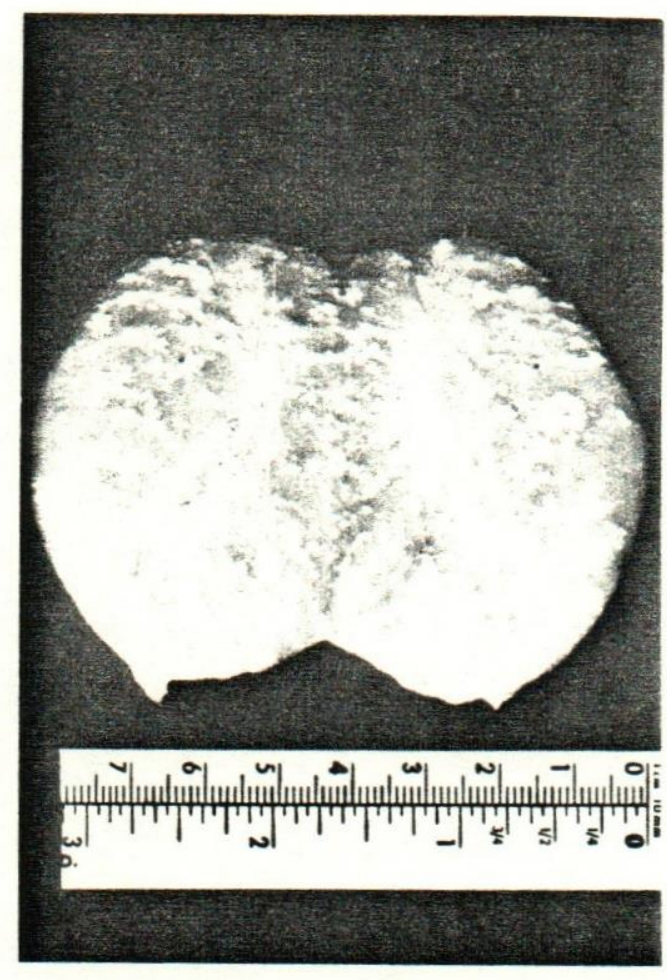

Fig. (3)

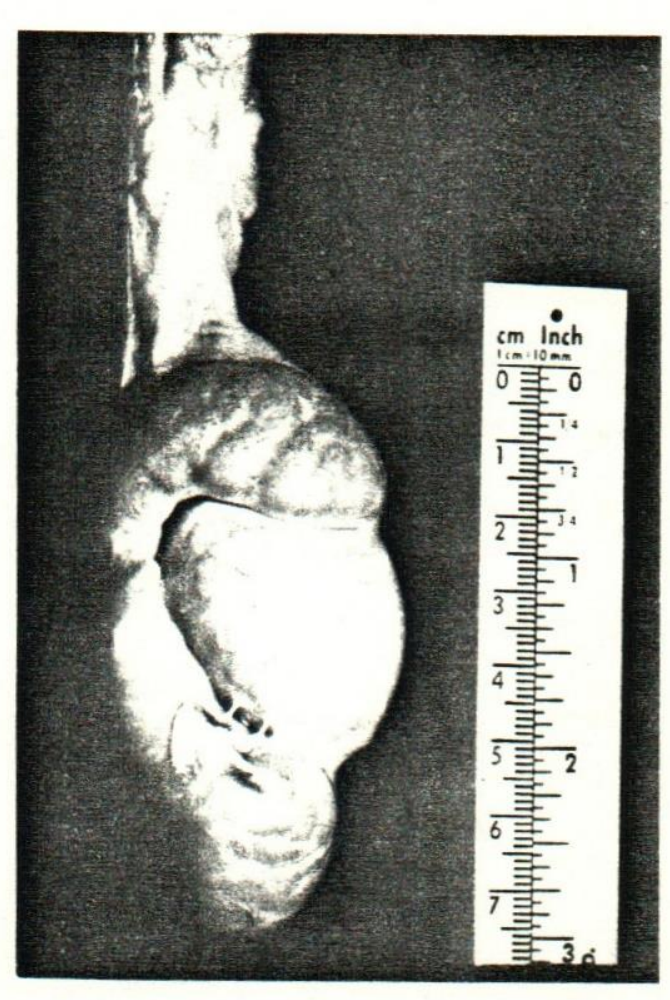

Fig. (2)

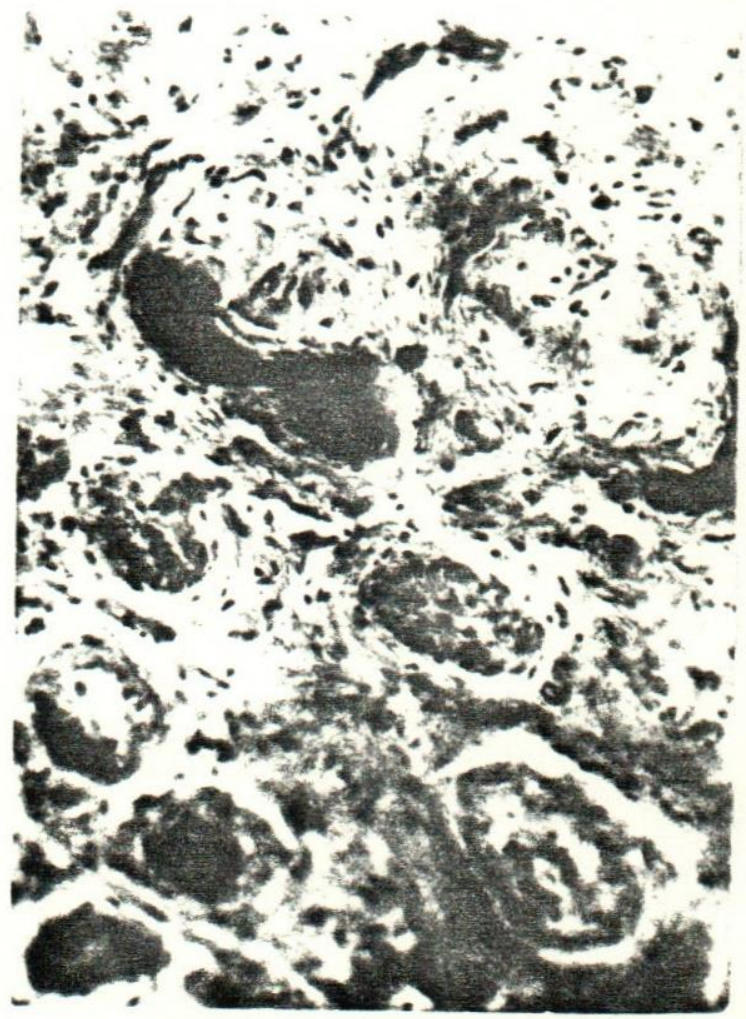

Fig. (4) 
$-$

*

4 . 

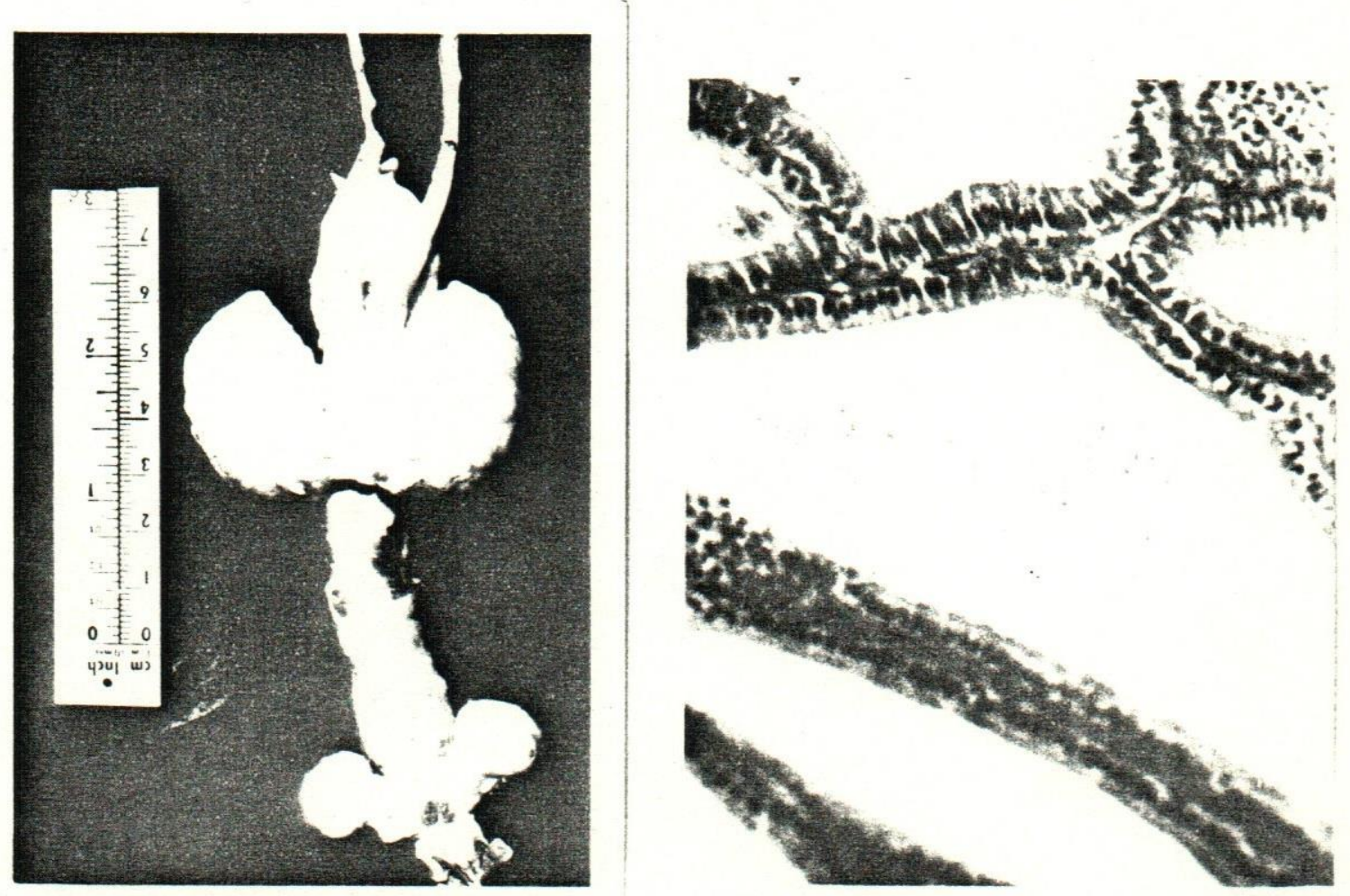

Fig. (5)

Fig. (6)
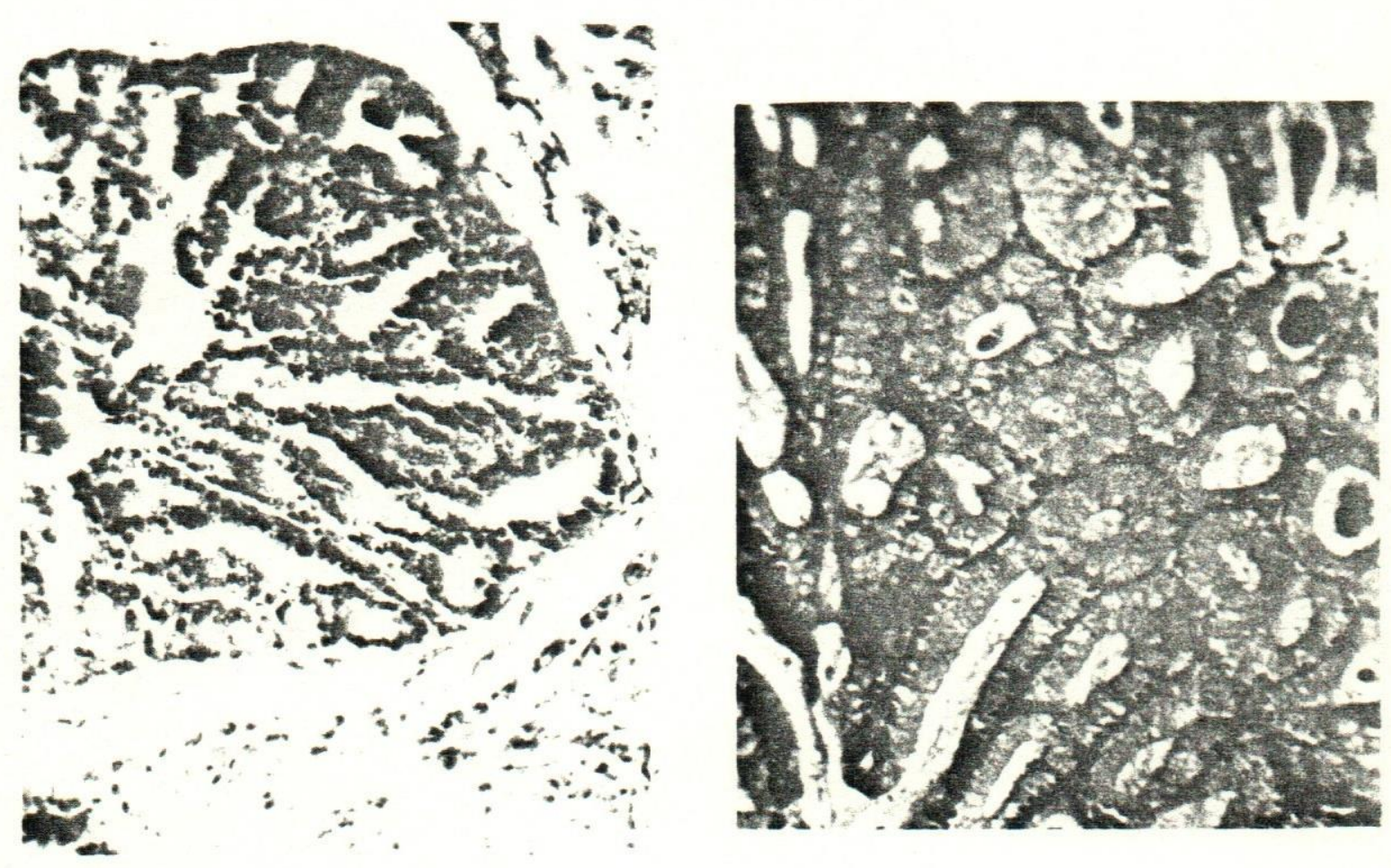

Fig. (7)

Fig. (8) 


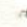

